\title{
NMR identification of calcineurin $B$ residues affected by binding of a calcineurin A peptide
}

\author{
Jacob Anglister ${ }^{\mathrm{a}, \mathrm{c}}$, Hao Ren ${ }^{\mathrm{b}}$, Claude B. Klee ${ }^{\mathrm{b}}, \mathrm{Ad} \mathrm{Bax}^{\mathrm{a}, *}$ \\ ${ }^{a}$ Laboratory of Chemical Physics, National Institute of Diabetes and Digestive and Kidney Diseases, National Institutes of Health, \\ Bethesda, MD 20892-0520, USA \\ ${ }^{\mathrm{b}}$ Laboratory of Biochemistry, National Cancer Institute, National Institutes of Health, Bethesda, MD 20892-0520, USA \\ ${ }^{\mathrm{c}}$ Department of Structural Biology, Weizmann Institute of Science, Rehovot 76100, Israel
}

Received 30 August 1995

\begin{abstract}
Triple resonance 3D NMR methods have been used to study the interaction between calcineurin $B$ and a peptide fragment of calcineurin $A$ for which it has high affinity $\left(K_{\mathrm{D}}\right.$ $\left.\sim 4 \times 10^{-7} \mathrm{M}\right)$. Although calcineurin $B$ aggregates at NMR concentrations of $\sim 1 \mathrm{mM}$, in the presence of a target peptide fragment of calcineurin $A$ it becomes monomeric and yields NMR spectra that are very similar to those reported previously for calcineurin B solubilized by the zwitterionic detergent CHAPS. Changes in chemical shifts between CHAPS- and peptide-solubilized calcineurin $B$ are small which is indicative of no differences in secondary structure. Residues most affected by binding to target peptide are found primarily on the hydrophobic faces of the four helices, present in each of the two globular domains in calcineurin B, and in the loops connecting helices II and III, IV and $\mathrm{V}$, and possibly in the C-terminal 12 residues, which also exhibit a change in mobility.
\end{abstract}

Key words: Calcineurin; NMR; CHAPS; Peptide-protein interaction

\section{Introduction}

Calcineurin is a $\mathrm{Ca}^{2+}$ - and calmodulin-stimulated Ser/Thrphosphatase, present in all eukaryotic cells, including nerve cells and $T$ cells [1]. It consists of two tightly bound subunits, calcineurin $\mathrm{A}(\mathrm{CnA})$ and calcineurin $\mathrm{B}(\mathrm{CnB})$, with molecular masses of 59 and $19.3 \mathrm{kDa}$, respectively. $\mathrm{CnA}$ also binds to calmodulin. The two calcium-binding proteins, $\mathrm{CnB}$ and calmodulin, are essential for the phosphatase activity of $\mathrm{CnA}$ [1]. Phosphatase activity is inhibited by the immunophilin-immunosuppressant complexes FKBP-FK506 and cyclophilin-cyclosporin A [2-5]. Calcineurin plays a key role in activating $\mathrm{T}$ cells, and its inhibition blocks dephosphorylation of the cytoplasmic subunit of the transcription factor NF-AT, NF-ATc, thereby blocking the transcription of cytokine genes and $\mathrm{T}$ cell

*Corresponding author. Fax: (1) (301) 4020907.

E-mail: bax@nih.gov

Abbreviations: $\mathrm{CBCA}(\mathrm{CO}) \mathrm{NH}, 3 \mathrm{D}\left({ }^{13} \mathrm{C}^{\alpha},{ }^{13} \mathrm{C}^{\beta}\right)-{ }^{15} \mathrm{~N}-{ }^{1} \mathrm{H}$ spectrum correlating amide ${ }^{1} \mathrm{H}$ and ${ }^{15} \mathrm{~N}$ with $\mathrm{C}^{\alpha}$ and $\mathrm{C}^{\beta}$ shifts of the preceding residue; CBCANH, 3D $\left({ }^{13} \mathrm{C}^{\alpha},{ }^{13} \mathrm{C}^{\beta}\right)-{ }^{15} \mathrm{~N}-{ }^{1} \mathrm{H}$ spectrum correlating amide ${ }^{1} \mathrm{H}$ and ${ }^{15} \mathrm{~N}$ with sequential and intraresidue $\mathrm{C}^{\alpha}$ and $\mathrm{C}^{\beta}$ shifts; $\mathrm{CnA}$, calcineurin A; CnB, calcineurin B; CHAPS, 3-[(3-cholamidopropyl)-dimethyl-ammonio]-1-propanesulfonate; FKBP, FK506-binding protein; HNCA, $3 \mathrm{D}^{1} \mathrm{H}-{ }^{15} \mathrm{~N}-{ }^{13} \mathrm{C}^{\alpha}$ correlation; HSQC, heteronuclear single quantum correlation; NF-AT, nerve factor of activated T cells; NF-AT , cytoplasmic subunit of NF-AT. activation [6]. Cross-linking experiments between cyclophilincyclosporin A or FK506-FKBP and calcineurin (both A and B subunits) suggested that the immunophilin-immunosuppressant complexes interact primarily with the $\mathrm{CnB}$ subunit but only when bound to $\mathrm{CnA}$ [7]. However, subsequent mutagenesis experiments showed that certain $\mathrm{CnA}$ mutants were capable of binding $\mathrm{CnB}$, but these mutant complexes would not bind to immunophilin-drug complexes, casting some doubts on an exclusive $\mathrm{CnB} / \mathrm{immunophilin-drug}$ interaction [8]. The structure of the complex between $\mathrm{CnA}, \mathrm{CnB}, \mathrm{FKBP}$ and FK506 has been solved very recently by X-ray crystallography and confirms that the FKBP-FK506 complex includes direct interactions with both the $\mathrm{CnA}$ and $\mathrm{CnB}$ subunits [9].

The amino acid sequence of $\mathrm{CnB}$ suggests the presence of four calcium-binding sites of the EF-hand helix-loop-helix (HLH) type [10] and these 12-residue sites are 54\% identical with those in calmodulin; outside these calcium-binding sites the degree of sequence identity is only $20 \%$. A recent NMR study confirms that the four calcium-binding sites are of the all-oxygen coordinating type and adopt a pentagonal bipyramidal geometry [11]. A previous triple resonance multidimensional NMR study of $\mathrm{CnB}$, solubilized by the zwitterionic detergent CHAPS, indicated substantial structural homology with calmodulin, including the presence of eight $\alpha$-helices, and a break in the 'central helix', similar to the one previously noted for calmodulin [12]. The length of the various helices was found to be substantially different, however. A modeling study also had suggested a similar structure for calmodulin and $\mathrm{CnB}$ [13].

The present report describes the results of an NMR study of the complex between genetically engineered $\mathrm{CnB}$, lacking $\mathrm{N}$ terminal myristoylation, and a 32-residue peptide fragment of CnA. This peptide fragment is one residue longer than the minimal peptide previously implicated in $\mathrm{CnA}$ binding [14] and 7 residues shorter at its $\mathrm{C}$-terminus than the $\mathrm{CnA}$ sequence found to contact $\mathrm{CnB}$ in the crystal structure [9]. However, out of a large array of peptide fragments (H. Ren and C.B. Klee, to be published), the fragment used in the present study was the only one which yielded rotational diffusion consistent with a monomeric structure for the CnB-peptide complex at NMR concentrations.

\section{Materials and methods}

\subsection{Sample preparation}

$\mathrm{CnB}$ was prepared and purified as described previously [15]. $\mathrm{CnB}$ was uniformly labeled with either ${ }^{15} \mathrm{~N}$ (for ${ }^{15} \mathrm{~N}-{ }^{-1} \mathrm{H}$ correlation) or both ${ }^{15} \mathrm{~N}$ and ${ }^{13} \mathrm{C}$ for triple resonance $\mathrm{CBCA}(\mathrm{CO}) \mathrm{NH}[16], \mathrm{CBCANH}$ [17] and HNCA [18] experiments. The peptide P2465 (DDEQFNSSPH 
PYWLPNFMDV FTWSLPFVGE KV) was synthesized by Peptide Technology (Gaithersburg, MD). The peptide was purified by HPLC and subsequently a Pharmacia G10 gel-filtration column, pre-equilibrated with $50 \mathrm{mM} \mathrm{NH} \mathrm{NCO}_{3}, \mathrm{pH} 5.0$. A $1.5 \mathrm{mM}$ aqueous solution of $\mathrm{CnB}$ containing $200 \mathrm{mM} \mathrm{KCl}, 0.04 \% \mathrm{NaN}_{3}, 11 \mathrm{mM} \mathrm{CaCl}_{2}, 5 \% \mathrm{D}_{2} \mathrm{O}$ pH 5.8, was prepared. Solid peptide in a 1.1:1 molar ratio was added to the protein solution and the $\mathrm{pH}$ was readjusted to 5.8. An additional $15 \%$ molar excess of peptide was then added to ensure saturation of $\mathrm{CnB}$ with P2465. The sample was then dialyzed overnight using a collodion bag with a $10-\mathrm{kDa}$ cut-off to remove excess of peptide and the protein/peptide solution was concentrated to $1.5 \mathrm{mM}$. To reduce problems arising from evaporation and condensation of the solvent, caused by the relatively high temperature at which NMR spectra were recorded, a sample height of $5.2 \mathrm{~cm}$ was used and the part of the tube above the spinner was wrapped with foam insulation.

\subsection{NMR spectroscopy}

${ }^{15} \mathrm{~N}-1 \mathrm{H}$ correlation spectra were measured at 37,42 and $47^{\circ} \mathrm{C}$ and the $\mathrm{CBCA}(\mathrm{CO}) \mathrm{NH}, \mathrm{CBCANH}$ and $\mathrm{HNCA}$ spectra were recorded at $47^{\circ} \mathrm{C}$ ${ }^{1} \mathrm{H}^{\mathrm{N}} T_{2}$ relaxation times were measured on a Bruker DMX $500 \mathrm{MHz}$ spectrometer and all other spectra were recorded on a Bruker AMX 600 $\mathrm{MHz}$ spectrometer equipped with a triple resonance probehead and pulsed field gradients. Resonance assignments were based on three triple resonance experiments $\mathrm{CBCA}(\mathrm{CO}) \mathrm{NH}, \mathrm{CBCANH}$ and $\mathrm{HNCA}$, which all included pulsed field gradients and a WATERGATE scheme for suppression of the solvent signal [19]. The following number of complex points and acquisition times were used: $2 \mathrm{D}^{1} \mathrm{H}^{15} \mathrm{~N}$ correlation $\left({ }^{15} \mathrm{~N}, \mathrm{~F}_{1}\right) 256,153.6 \mathrm{~ms},\left({ }^{1} \mathrm{H}, \mathrm{F}_{2}\right) 1024,110.6 \mathrm{~ms} ; \mathrm{CBCA}(\mathrm{CO}) \mathrm{NH}\left({ }^{13} \mathrm{C}^{\alpha}-\right.$ $\left.{ }^{13} \mathrm{C}^{\beta}, \mathrm{F}_{1}\right) 52,6.2 \mathrm{~ms},\left({ }^{15} \mathrm{~N}, \mathrm{~F}_{2}\right) 36,22.3 \mathrm{~ms},\left({ }^{1} \mathrm{H}, \mathrm{F}_{3}\right) 512,55.3 \mathrm{~ms}$; CBCANH $\left({ }^{13} \mathrm{C}^{\alpha}{ }^{13} \mathrm{C}^{\beta}, \mathrm{F}_{1}\right) 52,6.2 \mathrm{~ms},\left({ }^{15} \mathrm{~N}, \mathrm{~F}_{2}\right) 36,22.3 \mathrm{~ms},\left({ }^{1} \mathrm{H}, \mathrm{F}_{3}\right) 512$, $55.3 \mathrm{~ms} ; \mathrm{HNCA}\left({ }^{15} \mathrm{~N}, \mathrm{~F}_{1}\right) 34,23.9 \mathrm{~ms},\left({ }^{13} \mathrm{C}^{\alpha}, \mathrm{F}_{2}\right) 46,11.04 \mathrm{~ms},\left({ }^{1} \mathrm{H}, \mathrm{F}_{3}\right)$ $512,55.3 \mathrm{~ms}$. Spectra were processed using the software package NMRPipe [20] and analysed using the programs PIPP and CAPP [21].

\section{Results}

The P2465 peptide corresponds to residues $333-361$ of the $\alpha$-form of $\mathrm{CnA}, \mathrm{CnA} \alpha$, and includes three additional acidic $\mathrm{N}$-terminal residues for solubilization. Addition of stoichiometric amounts of $\mathrm{P} 2465$ to $\mathrm{CnB}$ results in a remarkable improvement in the ${ }^{1} \mathrm{H}$ NMR spectrum, as evidenced by a large increase in the $T_{2}$ relaxation time of its amide protons. At $47^{\circ} \mathrm{C}$, the use of substoichiometric amounts of peptide results in less line narrowing but the positions of the resolved resonances are not shifted towards those of the multimeric (aggregated) state. This indicates that the off-rate for the peptide is on the order of $\sim 100$ $\mathrm{s}^{-1}$. Its $K_{\mathrm{d}}$ was measured by sedimentation equilibrium to be $4.3 \times 10^{-7}$ at $20^{\circ} \mathrm{C}$ (H. Ren and C. B. Klee, to be published). As reported previously, the mean $T_{2}$ value for the downfield shifted amide protons is a convenient marker for the protein's rotational correlation time, $\tau_{\mathrm{c}}$, and an empirical formula $\tau_{\mathrm{c}}=10^{-9} /\left(5 T_{2}\right) \mathrm{s}^{2}$ has been proposed [22]. Using stoichiometric amounts of $\mathrm{P} 2465$, maximal $T_{2}$ values (in the 19-25 ms range) were obtained in $\mathrm{CnB}$ solutions containing $200 \mathrm{mM} \mathrm{KCl}$ at $\mathrm{pH}$ 5.9 and $47^{\circ} \mathrm{C}$. At $37^{\circ} \mathrm{C}, T_{2}$ values are in the $17-21 \mathrm{~ms}$ range, which compares to $\sim 11 \mathrm{~ms}$ for free $\mathrm{CnB}$, and $20 \mathrm{~ms}$ in the presence of CHAPS. The ${ }^{1} \mathrm{H}-{ }^{15} \mathrm{~N}$ HSQC [23] correlation spectrum (Fig. 1) reveals that at temperatures lower than $47^{\circ} \mathrm{C}$ some of the amides have much shorter $T_{2}$ values than others, indicative of conformational exchange on a micro- to millisecond time scale (vide infra) which becomes faster at higher temperatures. All multidimensional triple resonance experiments therefore were carried out at $47^{\circ} \mathrm{C}$ and the complex was found to be stable at this temperature for the time needed to record all 3D NMR spectra.

The sequential assignment of the protein was accomplished using $\mathrm{CBCA}(\mathrm{CO}) \mathrm{NH}, \mathrm{CBCANH}$ and HNCA spectra. In con-

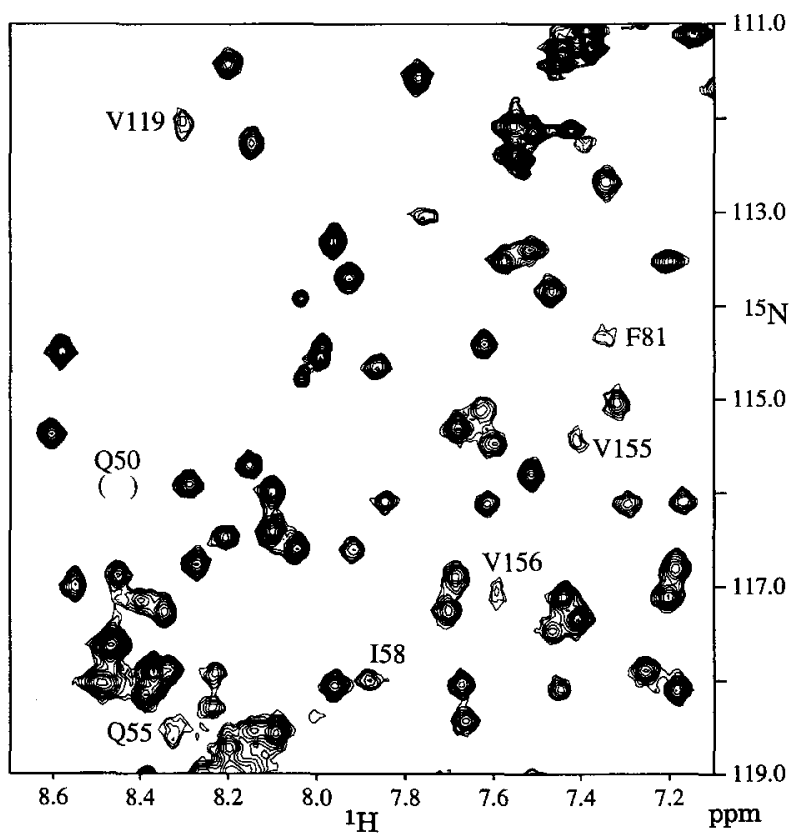

Fig. 1. A section of the $600 \mathrm{MHz}{ }^{1} \mathrm{H}^{-15} \mathrm{~N}$ HSQC spectrum of $\mathrm{CnB}$, complexed with the peptide $\mathrm{P} 2465$, recorded at $42^{\circ} \mathrm{C}$. Residues with considerably weaker cross-peaks at $42^{\circ} \mathrm{C}$ relative to their appearance at $47^{\circ} \mathrm{C}$ are labeled. The cross-peak of Q50 was not detected at $42^{\circ} \mathrm{C}$ and its position at $47^{\circ} \mathrm{C}$ is marked by parentheses.

trast with our previous study of $\mathrm{CnB}$ [15], monomerized by CHAPS, the CBCA(CO)NH and the HNCA spectra for the CnB-peptide complex yielded cross-peaks for all but the $\mathrm{N}$ terminal amino acid residue, allowing a complete sequential assignment.

The deviations of the $C^{\alpha}$ and $C^{\beta}$ chemical shifts from their random coil values are commonly used as markers for secondary structure $[25,26]$. These deviations from random coil chemical shifts are presented in Fig. 2. The changes in chemical shifts between the P2465-CnB complex and CHAPS-CnB are presented in Fig. 3. These changes are smaller than, for example, the chemical shift changes observed in calmodulin upon complexation with its target peptide of myosin light chain kinase [24]. The absence of significant changes in $\mathrm{C}^{\alpha}$ and $\mathrm{C}^{\beta}$ chemical shifts indicates that the secondary structure of $\mathrm{CnB}$ is the same in the CHAPS-monomerized form and in its complex with P2465.

The effect of temperature on the ${ }^{1} \mathrm{H}^{\mathrm{N}}$ and ${ }^{15} \mathrm{~N}$ chemical shifts has been analysed by recording ${ }^{15} \mathrm{~N}-{ }^{1} \mathrm{H}$ HSQC spectra at 37,42 and $47^{\circ} \mathrm{C}$ and chemical shift changes were found to be very small. These spectra also revealed the presence of conformational exchange on an intermediate time scale $(\mu \mathrm{s}-\mathrm{ms})$ : The resonances of L45, Q49, N51, I58, D59, D62, M118, V132 and $\mathrm{T} 135$ are significantly weaker at $37^{\circ} \mathrm{C}$ compared to their intensity at $47^{\circ} \mathrm{C} ; \mathrm{F} 81, \mathrm{~V} 119$ and V155 are much weaker, and E47, Q50 and V156 disappear altogether at $37^{\circ} \mathrm{C}$.

In CHAPS-CnB, the N-terminal residues (1-14), the C-terminal residues (158-169) and the linker connecting the two domains (residues 81-86) show increased mobility as judged by narrow, intense ${ }^{15} \mathrm{~N}-{ }^{1} \mathrm{H}$ cross-peaks and relatively fast amide proton exchange $[15,27]$. In CnB-P2465, only the $\mathrm{N}$-terminus and the last three $\mathrm{C}$-terminal residues retain this increased 

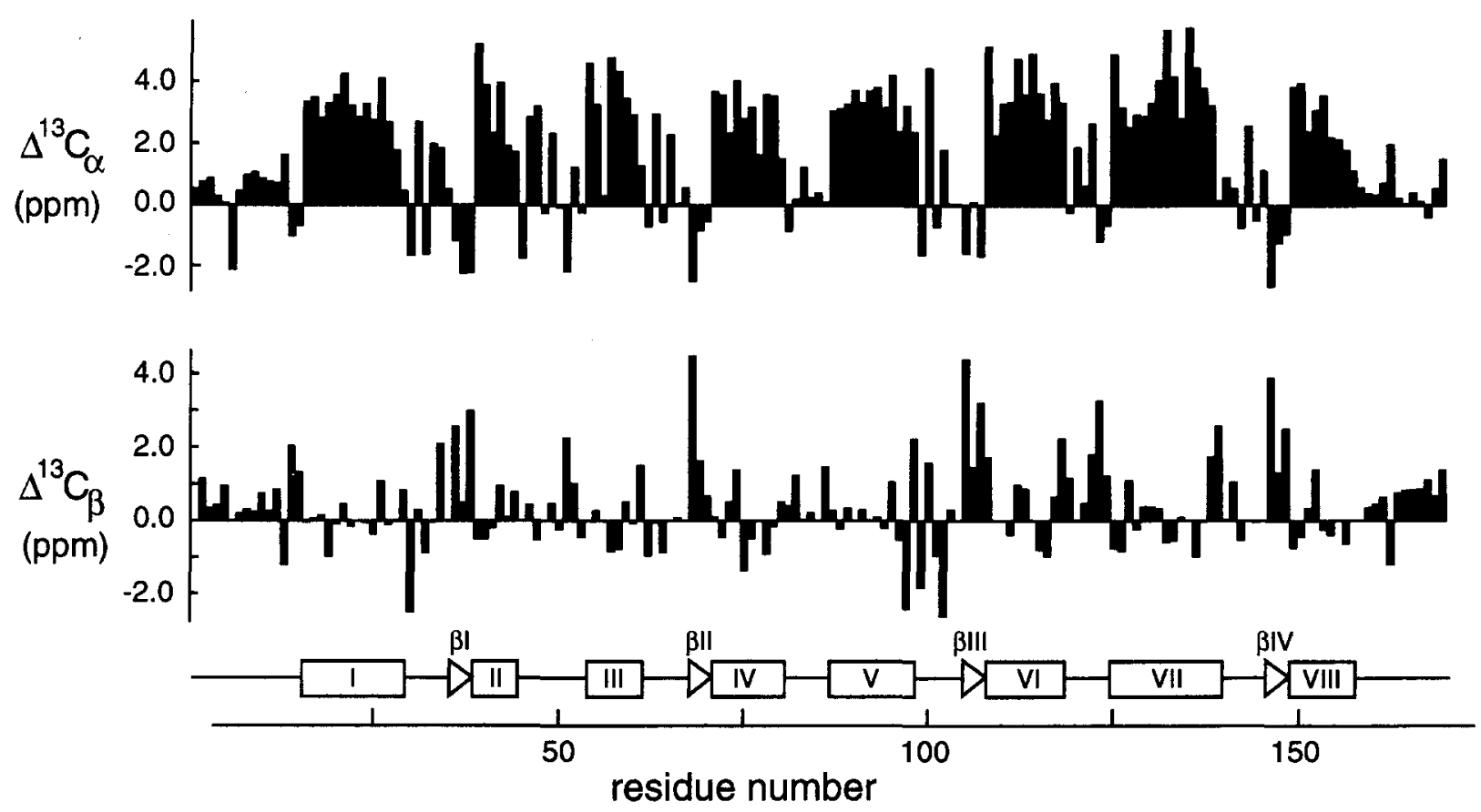

Fig. 2. The ${ }^{13} \mathrm{C}^{\alpha}$ and ${ }^{13} \mathrm{C}^{\beta}$ secondary shifts $\left(\Delta^{13} \mathrm{C}^{\alpha}\right.$ and $\left.\Delta^{13} \mathrm{C}^{\beta}\right)$ of $\mathrm{CnB}$ complexed with $\mathrm{P} 2465$. The secondary structure, deduced from these deviations from random coil chemical shifts, and confirmed by ${ }^{1} \mathrm{H}-{ }^{1} \mathrm{H}$ NOEs in CHAPS-solubilized $\mathrm{CnB}$, is also indicated.

mobility. The segment connecting the two domains actually shows weaker-than-average correlations, indicating slow to intermediate conformational exchange rates in this area.

\section{Discussion}

The small magnitude of the changes in chemical shifts of the $\mathrm{CnB}$ backbone and ${ }^{13} \mathrm{C}^{\beta}$ nuclei indicate that $\mathrm{CnB}$ retains the same secondary structure upon binding to the $\mathrm{CnA}$ peptide. The small changes in chemical shifts that are observed are not localized to a small number of residues or short segments in the polypeptide sequence. However, residues in the four 12-residue calcium-binding sites are affected less than their adjacent helices and the loops connecting these helices. Chemical shift changes in helices VI and VII, and the loop connecting VI and VII also are smaller than average. The smaller-than-expected magnitude of the chemical shift changes upon complexation with $\mathrm{P} 2465$ may be due to the fact that the CnB-binding site was previously occupied by CHAPS, and that the change at the interaction interface is less dramatic than changing a solventexposed hydrophobic protein surface to one that interacts with a hydrophobic target peptide. In the present case, the chemical shift changes are therefore a less pronounced indicator for identifying the interaction surface.

The X-ray crystal structure of calcineurin, complexed with FKBP and FK 506 but not calmodulin, was solved very recently at a resolution of $2.5 \AA$ [9]. It is interesting to compare our NMR observations with this X-ray structure. The crystal structure indicates a decrease in the $\mathrm{CnB}$ solvent accessible surface area by $1681 \AA^{2}$. This is about twice the size of the contact area between lysozyme and its specific antibody [28]. This large contact area for a relatively small protein explains why the changes in chemical shifts are not limited to a small and welldefined region.
The peptide used in our NMR study lacks seven C-terminal residues relative to the $\mathrm{CnA}$ helix interacting with $\mathrm{CnB}$, and use of the full peptide does not yield monomeric behavior for the peptide-CnB complex. The above noted slow conformational exchange, affecting primarily the amides of residues 45-62 in $\mathrm{CnB}$, may be caused by the fact that in the full complex this segment interacts with the residues that are missing in P2465. Similarly, residues M118 and V119, which are also subject to slow conformational averaging in the NMR spectra, interact with the FKBP-FK506 complex in the crystal structure. Indeed, in the absence of intermolecular interactions, the binding sites of proteins frequently experience increased conformational flexibility. For example, the backbone atoms of $\mathrm{H} 87$ through I90 of the FKBP-FK 506 complex bound to calcineurin are reported to shift by $1 \AA$ relative to the structure of the FKBPFK506 complex alone [9]. The lowest heteronuclear ${ }^{15} \mathrm{~N}-{ }^{1} \mathrm{H}$ NOE in the FKBP-FK 506 complex is observed for H87, indicative of significant backbone motions occurring on a time scale of $\sim 1 \mathrm{~ns}[29]$.

The previously mentioned decrease in rapid large amplitude motions for CnB residues 81-86, which connect the $\mathrm{N}$ - and C-terminal domains, upon complexation with P2465 is consistent with the X-ray structure of the complex, in which this linker now interacts with the target peptide [9]. The C-terminal 12 residues also lose their high degree of mobility upon peptide binding. In the $\mathrm{X}$-ray structure, this $\mathrm{C}$-terminus forms an extended strand which lies parallel to the CnA helical target site and interacts with both $\mathrm{CnA}$ and $\mathrm{CnB}$. Although such a conformation would explain the decrease in mobility observed for these residues, the chemical shift changes upon complexation of P2465 are smaller than expected for a change from a random coil to a fully extended conformation and it remains unclear whether this interaction actually occurs in the P2465-CnB complex or not. 


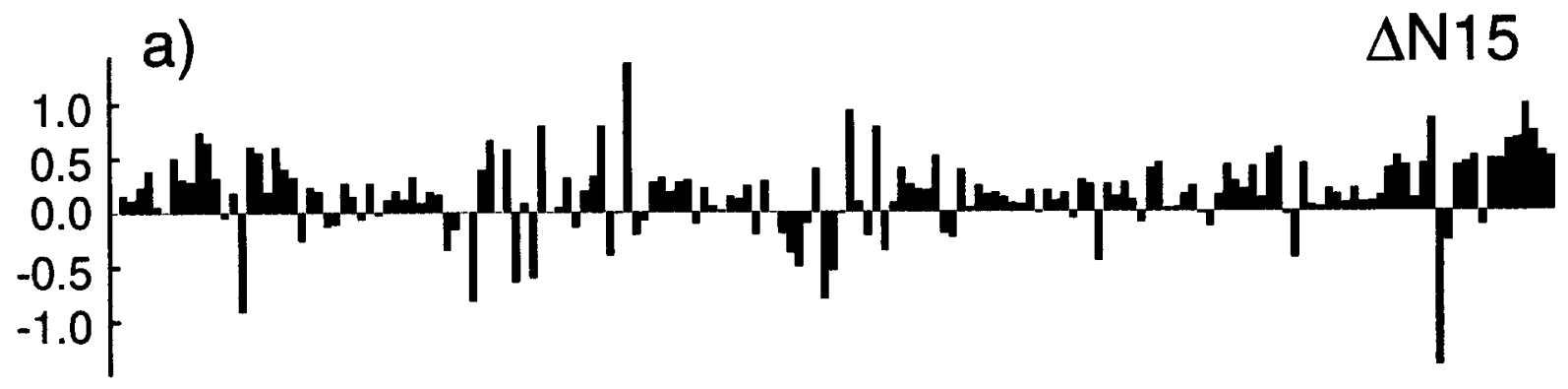

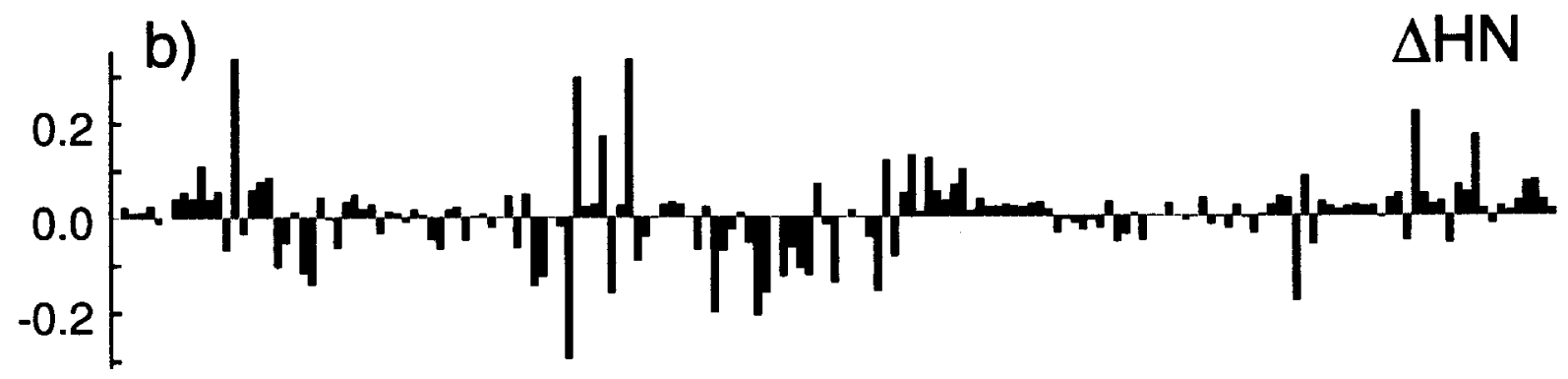

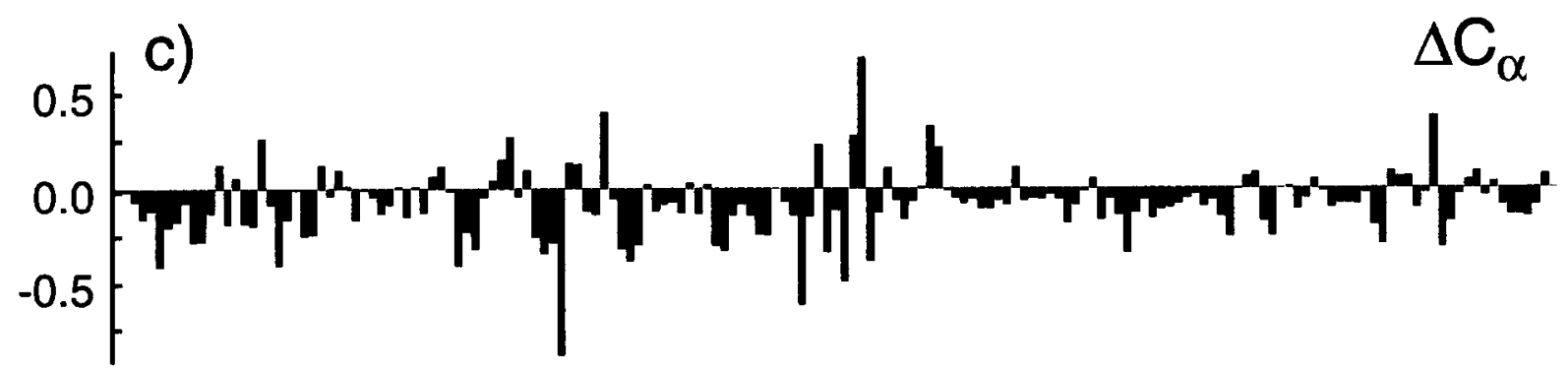

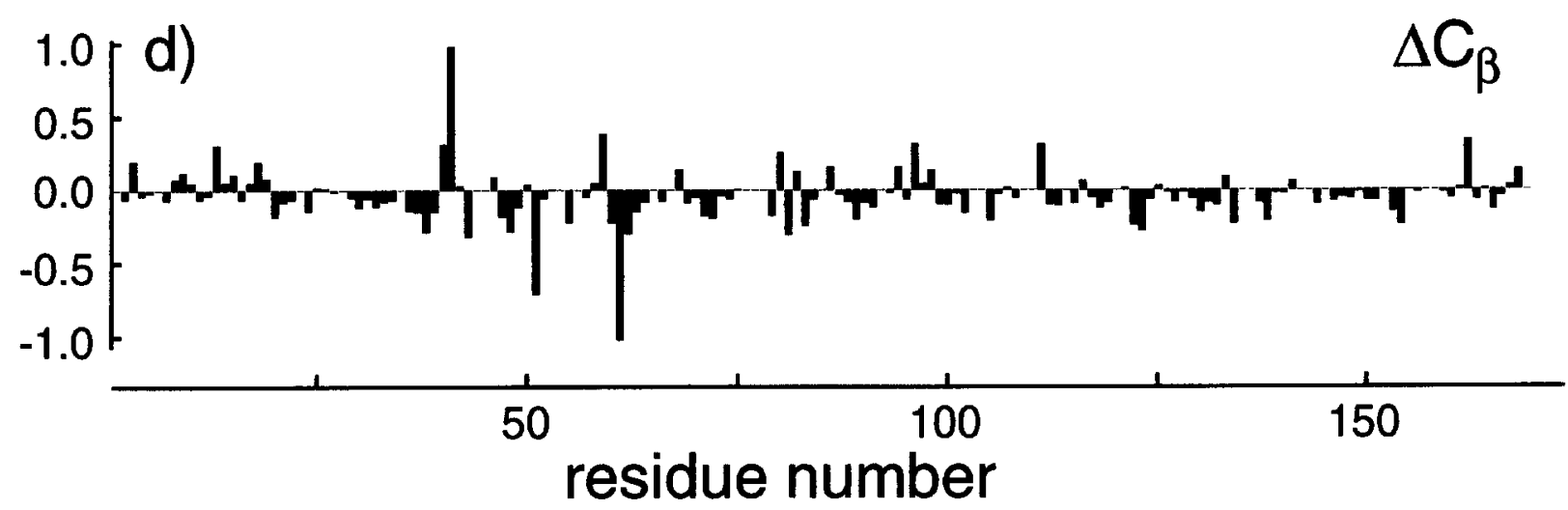

Fig. 3. Plots of the change in chemical shift for ${ }^{1} \mathrm{H}^{\mathrm{N}},{ }^{15} \mathrm{~N},{ }^{13} \mathrm{C}^{\alpha}$ and ${ }^{13} \mathrm{C}^{\beta}$, occurring upon complexation of $\mathrm{CnB}$ with $\mathrm{P} 2465$, relative to the values of CHAPS-CnB. The ${ }^{1} \mathrm{H}^{\mathrm{N}}$ and ${ }^{15} \mathrm{~N}$ chemical shifts in both cases correspond to $37^{\circ} \mathrm{C}$, whereas the ${ }^{13} \mathrm{C}^{\alpha}$ and ${ }^{13} \mathrm{C}^{\beta}$ shifts for the complex with $\mathrm{P} 2465$ correspond to $47^{\circ} \mathrm{C}$. A complete table of ${ }^{1} \mathrm{H}^{\mathrm{N}},{ }^{15} \mathrm{~N},{ }^{13} \mathrm{C}^{\alpha}$ and ${ }^{13} \mathrm{C}^{\beta}$ chemical shifts will be deposited with the BMRB data bank (Madison, WI).

The CnB secondary structure, as identified from the deviations from random coil ${ }^{13} \mathrm{C}^{\alpha}$ and ${ }^{13} \mathrm{C}^{\beta}$ chemical shifts, is identical with that reported previously [15] and agrees quite well with that observed in the X-ray structure, except for some minor differences which presumably are largely semantic. For example, Griffith et al. [9] include S38 in helix II, whereas our NMR data identify this residue as the $\mathrm{N}$-cap for this helix on the basis of its $\mathrm{C}^{\alpha}$ and $\mathrm{C}^{\beta}$ chemical shifts [30]. The only minor discrepancies appear to be at the C-terminal end of helix II, which according to the NMR data extends to S44, and terminates at F42 according to the X-ray, and the last helix, VIII, which appears to be fraying and extends to G157 in the NMR data, but terminates at V155 in the X-ray definition. In both these instances, the chemical shifts of the two residues involved are 
intermediate between helical and random coil values, and the difference in secondary structure is therefore unlikely to be significant.

Comparison of the crystal structure of the calcineurin complex with our NMR study of CnB and its complex with P2465 provides support for two complementary approaches for studying large intermolecular complexes by NMR. First, the detergent CHAPS indeed can reduce aggregation without perturbing the protein's structure. Second, peptide fragments of the other subunit, even if considerably shorter than the full length that interacts with the protein of interest, can be used to alleviate aggregation problems encountered with the free subunit.

Acknowledgements: We thank Nico Tjandra for help with recording the CBCA(CO)NH and CBCANH spectra and John Marquardt for his assistance in preparing Figs. 2 and 3. This work was supported by the Intramural AIDS-Directed Antiviral Program of the Office of the Director of the National Institutes of Health and by a grant from the US-Israel Binational Science Foundation (92-337) (J.A.).

\section{References}

[1] Klee, C.B., Draetta, G. and Hubbard, M. (1987) Adv. Enzymol. $61,149-200$

[2] Liu, J., Farmer, J.D., Jr., Lane, W.S., Friedman, J., Weissman, I. and Schreiber, S.L. (1991) Cell 66, 807-815.

[3] Liu, J., Albers, M.W., Wandless, T.J., Luan, S., Alberg, D.G., Belshaw, P.J., Cohen, P., MacKintosh, C., Klee, C.B. and Schreiber, S.L. (1992) Biochemistry 31, 3896-3901.

[4] Schreiber, S.L. (1992) Cell 70, 365-368.

[5] Schreiber, S.L. and Crabtree, G.R. (1992) Immunol. Today 13, 136-142.

[6] McCaffrey, P.G., Perrino, B.A., Soderling, T.R. and Rao, A. (1993) J. Biol. Chem. 268, 3747-3752.

[7] Li, W. and Handschumacher, R.E. (1993) J. Biol. Chem. 268, 14040-14044.

[8] Clipstone, N.A., Fiorentino, D.F. and Crabtree, G.R. (1994) J. Biol. Chem. 269, 26431-26437.
[9] Griffith, J.P., Kim, J.L., Kim, E.E., Sintchak, M.D., Thomson, J.A., Fitzgibbon, M.D., Fleming, M.A., Caron, P.R., Hsiao, K. and Navia, M.A. (1995) Cell 82, 507-522.

[10] Aitken, A., Klee, C.B. and Cohen, P. (1984) Eur. J. Biochem. 139, 663-671.

[11] Kakalis, L.T., Kennedy, M., Sikkink, R., Rusnak, F. and Armitage, I. (1995) FEBS Lett. 362, 55-58.

[12] Barbato, G., Ikura, M., Kay, L.E. and Bax, A. (1992) Biochemistry $31,5269-5278$.

[13] West, S., Bamborough, P. and Tully, R. (1993) J. Mol. Graphics $1,47-52$.

[14] Husi, H., Luyten, M.A. and Zurini, M.G.M. (1994) J. Biol. Chem. 269, 14199-14204.

[15] Anglister, J., Grzesiek, S., Wang, A.C., Ren, H., Klee, C.B. and Bax, A. (1994) Biochemistry 33, 3540-3547.

[16] Grzesiek, S. and Bax, A. (1992) J. Am. Chem. Soc. 114, 62916293.

[17] Grzesiek, S. and Bax, A. (1992) J. Magn. Reson. 99, 201-207.

[18] Grzesiek, S. and Bax, A. (1992) J. Magn. Reson. 96, 432-440.

[19] Piotto, M., Saudek, V. and Sklenar, V. (1992) J. Biomol. NMR 2, 661-665.

[20] F. Delaglio, F., Grzesiek, S., Vuister, G.W., Zhu, G., Pfeifer, J. and Bax, A. (in press) J. Biomol. NMR.

[21] Garrett, D.S., Powers, R., Gronenborn, A.M. and Clore, G.M. (1991) J. Magn. Reson. 95, 214-220.

[22] Anglister, J., Grzesiek, S., Ren, J., Klee, C.B. and Bax, A. (1993) J. Biomol. NMR 3, 121-126.

[23] Bodenhausen, G. and Ruben, D.J. (1980) Chem. Phys. Lett. 69, $185-188$.

[24] Ikura, M., Kay, L.E., Krinks, M. and Bax, A. (1991) Biochemistry $30,5498-5504$.

[25] Wishart, D.S., Sykes, B.D. and Richards, F.M. (1991) J. Mol. Biol. $222,311-333$.

[26] Spera, S. and Bax, A. (1991) J. Am. Chem. Soc. 113, 54905492.

[27] Grzesiek, S. and Bax, A. (1993) J. Biomol. NMR 3, 627-638.

[28] Amit, A.G., Mariuzza, R.A., Phillips, S.E.V. and Poljak, R.J. (1986) Science 233, 747-753.

[29] Cheng, J.-W., Lepre, C.A. and Moore, J.M. (1994) Biochemistry $33,4093-4100$

[30] Gronenborn, A.M. and Clore, G.M. (1994) J. Biomol. NMR 4, $455-458$. 